\title{
IMOVINA, NETO IMOVINA (KAPITAL) I OSNOVNI KAPITAL PRIVREDNOG DRUŠTVA
}

\author{
Velisav Marković \\ Poslovni fakultet u Valjevu, Univerzitet Singidunum, Valjevo, Srbija
}

\begin{abstract}
Apstrakt:
Zakonom o privrednim društvima je definisano da imovinu društva čine stvari i prava u vlasništvu društva, kao i druga pravna društva; da je neto imovina (kapital) privrednog društva razlika između vrednosti imovine i obaveza društva; da je osnovni (registrovani) kapital društva novčana vrednost upisanih uloga članova društva u društvo, koja je registrovana u skladu sa zakonom o registraciji. Navedene definicije su laičke i neprecizne što može stvoriti problem u poslovnoj praksi. U ovom radu autor analizira osnovne pravne pojmove imovine, neto imovine i osnovnog kapitala privrednog društva kako bi ih što više osvetlio i učinio razumljivim.
\end{abstract}

\section{Ključne reči:}

imovina,

imovina privrednog društva, neto imovina (kapital), osnovni kapital.

\section{UVOD}

U poslovnoj praksi pa i pravnoj teoriji postoje različita shvatanja pojma imovine privrednog društva, pa samim tim i neto imovine i osnovnog kapitala privrednog društva. Tome doprinosi najpre nepravilna zakonska definicija pojma imovine privrednog društva, jer Zakon o privrednim društvima ${ }^{1}$, u daljem tekstu: ZPD, uređuje da imovinu društva u smislu ovog zakona čine stvari i prava u vlasništvu društva, kao i druga prava društva (član 44. stav 1.).

Svrha ovog rada jeste analiza i razjašnjavanje osnovnih pojmova imovine, neto imovine i osnovnog kapitala privrednog društva radi njihovog pravilnog shvatanja i razumevanja kako bi se izbegli problemi u poslovnoj praksi.

\section{POJAM IMOVINE}

Imovina je skup svih subjektivnih imovinskih prava jednog lica. Predmet imovine su: stvarna prava, intelektualna imovinska prava (autorska prava i prava industrijske svojine), prava ličnosti (ako su izražena u imovinskom vidu) i obligaciona prava (izuzev onih koja se ne mogu uopšte novčano izraziti).

Imovina se ne sastoji od aktive i pasive kao što se to ističe u našoj vladajućoj doktrini. Neki autori smatraju da je pojam imovine neodvojiv od aktive i pasive zajedno [11]. Aktiva bi, prema tom mišljenju, obuhvatala sva prava (relativna i apsolutna), a pasiva samo obaveze (relativna prava). Pasiva, međutim, nije deo imovine dužnika, a ni teret na imovini dužnika, nego imovina poverioca. Dug koji poverilac potražuje od dužnika čini imovinu poverioca, a ne pasivu koja ulazi u imovinu dužnika [2].

Svaki pravni subjekt ima jednu imovinu, a ona je, po pravilu, nerazdvojna od njega [8]. Imovina je nedeljiva i predstavlja jedinstvenu celinu. Pravna lica, kao i fizička lica, imaju svoju imovinu koja se razlikuje od imovine osnivača ili članova pravnog lica. Razlikuje se jasno i imovina ortaka od imovine ortačkog društva.
Objekti imovinskog prava mogu biti: stvari, radnje, lična dobra i intelektualna dobra. Povodom ovih objekata pravni subjekti su u imovinsko-pravnom odnosu.

Stvar je materijalni deo prirode u ljudskoj vlasti nad kojom postoji subjektivno imovinsko pravo. Materijalni deo prirode, određen kao stvar, mora ispunjavat fizičke i pravne pretpostavke. Fizička pretpostavka znači da deo prirode može biti u vlasti čoveka, a pravna pretpostavka zahteva da se na tom delu materijalne prirode može steći stvarno pravo ili neko drugo subjektivno imovinsko pravo.

Radnje su aktivna ili neaktivna ljudska ponašanja na koja je dužnik obavezan poveriocu na osnovu nekog obligacionog odnosa. Mogu se sastojati u davanju, činjenju, nečinjenju ili trpljenju. Radnje su objekat obligacionih odnosa, dok su stvari objekat stvarnopravnih odnosa.

Lična prava su prava imaoca na ličnim dobrima, kao što su: pravo na život, zdravlje, slobodu, čast, ugled, telesni, duhovni i moralni integritet, identitet, privatnost, ime, lik, glas. Ova prava se jednim delom štite imovinskim pravom i to samo ako se mogu izraziti u imovinskom vidu.

Intelektualna prava su tvorevine ljudskog uma koje za svoj predmet imaju autorska i pravo industrijske svojine (patent, uzorak, model, žig, geografsko poreklo i dr.). Ova prava pored moralne imaju i imovinskopravnu komponentu (pravo na iskorišćavanje dela ili pronalaska).

Imovinskopravni odnos je odnos između titulara subjektivnog imovinskog prava i lica prema kojima su uperena ta ovlašćenja, odnosno obaveznih lica. Imovinskopravni odnos obuhvata ovlašćenu stranu (titulara prava) i lica prema kome su uperena ovlašćenja titulara subjektivnog prava, odnosno obaveznog lica. Tako, vlasnik automobila, ima subjektivno stvarno pravo iz koga proističe obaveza držanja, upotrebe i raspolaganja tom stvari. Pravo svojine nameće dužnosti svih ostalih lica. Obligacioni odnos nastaje između poverioca i dužnika. Poverilac je ovlašćen zahtevati od dužnika ispunjenje obaveze, a dužnik je dužan ispuniti obavezu u svemu kako ona glasi [2]. 


\section{IMOVINA PRIVREDNOG DRUŠTVA}

Zakonom o privrednim društvima određeno je da imovinu društva u smislu ovog zakona čine stvari i prava u vlasništvu društva, kao i druga prava društva (član 44. stav 1.). Ovakva definicija imovine nije uobičajena i pravilna.

Naime, imovinu privrednog društva čine, po pravilu, stvarna prava na stvari $[3],{ }^{2}$ obligaciona prava i prava intelektualne svojine [4].

Dakle, imovinu privrednog društva ne mogu činiti stvari već prava na stvari (pravo svojine - najčešće na pokretnim i nepokretnim stvarima, pravo službenosti, pravo stvarnog tereta i pravo zaloge). ${ }^{3}$ Prava u vlasništvu društva i druga prava društva mogu biti obligaciona prava društva (pravo zakupa, pravo posluge i slično) i prava intelektualne svojine društva (prava industrijske svojine: patent, model, uzorak, žig, geografsko poreklo, autorska prava i dr.). ${ }^{4} \mathrm{Na}$ kraju prvog stava definicije pojma imovine kaže se da imovina obuhvata i druga prava, bez preciziranja o kojim pravima je reč. Osim imovinskih, postoje i neimovinska prava koja ne ulaze u sastav imovine. Pravna lica mogu imati i određena lična prava: čast, ugled, identitet, privatnost, osim onih koja su svojstvena fizičkim licima.

Dakle, imovina privrednog društva obuhvata celokupnost navedenih prava koja joj pripadaju.

Pravilniju definiciju imovine privrednog društva daje na primer Zakon o privrednim društvima Republike Srpske ${ }^{5}$ koji u članu 13. stav 11. uređuje da imovinu privrednog društva u smislu ovog zakona čini pravo svojine i druga imovinska prava koje društvo ima na ulozima ili je steklo poslovanjem. Takođe, pravilniju definiciju imovine davao je prethodni Zakon o privrednim društvima ${ }^{6}$ po kome imovinu društva u smislu ovog zakona čini pravo svojine i druga prava koje društvo ima na ulozima ili je steklo poslovanjem i Zakon o preduzećima ${ }^{7}$ po kojem imovinu preduzeća čini pravo svojine na pokretnim i nepokretnim stvarima, novčana sredstva i hartije od vrednosti i druga imovinska prava (član 50.).

Imovina privrednog društva je jedinstvena. Jedno privredno društvo može imati samo jednu imovinu kojom odgovara za svoje obaveze u izvršnom, likvidacionom ili stečajnom postupku. Podelom imovine po fondovima ili različitim preknjižavanjem, odgovornost za obaveze ne može se izbeći ili smanjiti (osim u zakonom propisanim slučajevima). Imovinska prava ne mogu istovremeno pripadati različitim licima (ovim se ne isključuje suvlasništvo više lica na određenoj stvari, ali tada obim procentualnog suvlasništva ulazi u imovinu svakog suvlasnka posebno). Obaveze ne čine imovinu, već su njeni tereti, jer imovinu čine samo prava. Otuda imovina nema aktivu i pasivu [13]. Neki autori imaju suprotno shvatanje: Imovina u uobičajenom značenju tog pojma obuhvata kako prava, tako i obaveze. Reč je o tzv. imovinskim pravima i obavezama, odnosno pravima i obavezama čija se vrednost može izraziti u novcu. Pojam imovine, tradicionalno obuhvata i aktivu i pasivu, odnosno sve što nekome pripada kao pravo ili obaveza imovinskog karaktera [11]

Vrednost imovine društva se ne poklapa sa vrednošću društva tj. cenom po kojoj vlasnik društva može prodati društvo.

2 Subjektivno stvarno pravo je građansko pravo koje svog imaoca ovlašćuje na neposrednu pravnu vlast na određenim stvarima. Predmet subjektivnog stvarnog prava je stvar neposredno.

3 Član 6. Stav 1. Zakona o osnovama svojinskopravnih odnosa, Službeni list SFRJ, br. 6/80, 36/90, Službeni list SRJ, br. 29/96, Službeni glasnik RS, br. 115/2005.

4 Intelektualna prava se još nazivaju i nematerijalna imovina. O nematerijalnoj imovini, metodama vrednovanja, tržišnoj i računovodstvenoj vrednosti vidi više u Stefanović, M., Nematerijalna imovina privrednog društva, Zbornik radova Pravnog fakulteta $u$ Nišu, broj 59/2012, str. 249-272.

5 Sl. glasnik RS, broj 127/08, 58/09, 100/11, 67/13

6 Sl. glasnik RS, broj 125/2004

7 Sl. list SRJ, broj 29/96, 29/97, 59/98, 74/99, 9/2001, 36/2002
Vrednost društva po kojoj ga vlasnik može prodati je uvećana i tzv. organizacionom imovinom društva, koja odvojena od imovine društva nema cenu, i to: poslovni ugled društva, mogućnost daljeg razvoja društva, broj i bonitet poslovnih partnera itd. [6]. Značaj poslovnih partnera u anglosaksonskom pravu izražava goodwill. To je prednost koja proizilazi iz reputacije i trgovačkih veza društva, posebno sa verovatnošću da će postojeća klijentela biti zadržana. Goodwill se određuje, stoga, kao razlika između ukupne vrednosti društva i odvojene vrednosti neto aktive društva [1].

\section{KAPITAL (NETO IMOVINA) PRIVREDNOG DRUŠTVA}

Neto imovina (kapital) privrednog društva jeste razlika između vrednosti imovine i obaveza društva (član 44. stav 2. ZPD). Neto imovina se određuje kao računska kategorija, kao razlika između vrednosti svih imovinskih prava društva i imovinskih obaveza društva.

Obaveze društva predstavljaju dugove društva, odnosno obligacioni odnos u kome je društvo u statusu dužnika sa obavezom davanja, činjenja, nečinjenja ili trpljenja izraženo u novčanom obliku.

Ako su obaveze (tereti) veći od imovine (prava), privredno društvo je prezaduženo ili insolventno, što vodi njegovom stečaju. Shodno odredbama člana 11. stav 5 . Zakona o stečaju ${ }^{8}$, prezaduženost postoji ako je imovina stečajnog dužnika manja od njegovih obaveza. Ako je stečajni dužnik društvo lica prezaduženost ne postoji ako to društvo ima najmanje jednog ortaka odnosno komplementara koji je fizičko lice.

Izuzetno, ako postoji neusklađenost ostvarivanja prava koja ulaze u imovinu i obaveza koje je terete, ali kad je imovina veća od obaveza, reč je o nelikvidnosti privrednog društva, što ne mora voditi i njegovoj prezaduženosti i insolventnosti i time stečaju.

Privredno društvo postoji sve dok postoji njegova imovina (aktiva), kao leva strana bilansa društva [13]. Ovo je naravno tačno pod uslovom da je reč o neto imovini društva, odnosno da je imovina društva veća od obaveza društva. Pod aktivom se, između ostalog, podrazumeva knjigovodstveno posmatranje imovine preduzeća sa stanovišta njenih pojavnih oblika [9].

U postupku likvidacije vrednost neto imovine društva se podudara sa vrednošću likvidacionog ostatka.

\section{OSNOVNI KAPITAL PRIVREDNOG DRUŠTVA}

Osnovni (registrovani) kapital društva je novčana vrednost upisanih uloga članova društva u društvo koja je registrovana u skladu sa zakonom o registraciji (član 44. stav 3. ZPD).

Ulozi u društvo mogu da budu novčani i nenovčani i izražavaju se u dinarima. Ako se uplata novčanog uloga vrši u stranoj valuti u skladu sa zakonom koji uređuje devizno poslovanje, dinarska protivvrednost uloga obračunava se po srednjem kursu Narodne banke Srbije na dan uplate uloga. Nenovčani ulozi mogu biti u stvarima i pravima, ako zakonom za pojedine forme društava nije drugačije određeno (član 45. ZPD). Ulozi u društvo mogu biti u novcu, naturi, radu i uslugama. Ulozi u radu i uslugama (koji su izvršeni ili tek treba da budu izvršeni) mogu biti samo u ortačka i komanditna društva.

Minimalni osnovni kapital društava kapitala propisan je zakonom, dok to nije slučaj kod društava lica, s obzirom da kod njih postoji neograničena odgovornost članova (ortaka i komplementara) za obaveze društva [7]. Tako je minimalni osnovni

8 Sl. glasnik RS, br. 104/2009, 99/2011, 71/2012 (Odluka Ustavnog suda, $83 / 2014$ 
kapital za društvo s ograničenom odgovornošću 100 dinara, za akcionarsko društvo 3.000.000 dinara. ${ }^{9}$

Po osnovu preuzete obaveze unošenja uloga lica stiču udeo u društvu, odnosno akcije društva a time i članska prava u društvu (pravo na upravljanje, pravo na učešće u dobiti, pravo na uvid u dokumentaciju i dr.). Nije moguće ulaganje u osnovni kapital, a da se ne stekne pravo na udeo.

Ulozi koji su uplaćeni, odnosno uneti u društvo postaju imovina društva. Osnovni kapital se određuje voljom članova društva, bilo prilikom osnivanja, bilo kasnije. Upisuje se u registar kod Agencije za privredne registre i ne zavisi od faktičkih promena u imovini društva. ${ }^{10}$ Vrednost osnovnog kapitala ostaje nepromenjena sve dok se ne promeni voljom osnivača, na odgovarajući način, bilo povećanjem, bilo smanjenjem, što podrazumeva i upis promene u registar kod Agencije za privredne registre [12].

Članovima društva ne može se izvršiti povraćaj uplaćenih, odnosno unetih uloga, niti im se može platiti kamata na ono što su uložili u društvo. Plaćanje cene kod sticanja sopstvenih udela odnosno akcija, kao ni druga plaćanja članovima društva koja se vrše u skladu sa ovim zakonom, ne smatraju se vraćanjem uloga članovima društva (član 60. ZPD). ${ }^{11}$

Upisani kapital postoji kao latentni kapital, odnosno obećanje uplate kapitala, jer ne predstavlja pravi kapital dok se ne uplati. Iz tih razloga u finansijskim izveštajima on se ne pojavljuje kao realnost, a ukoliko je evidentiran i iskazan on je u najbukvalnijem smislu fiktivna kategorija čija su protivteža u bilansnoj aktivi pisani, a neuplaćeni ulozi. U ovakvim situacijama redovno dolazi do toga da se finansijski i revizijski izveštaji ne podudaraju sa vrednostima iskazanim u dokumentima društva. Iz tih razloga, može doći do pogrešnog informisanja javnosti. Čini se da je neophodno istaći da se na nelogičan način već godinama koriste termini novčani i nenovčani kapital. Kapital je u aktivi realna imovina čak i kad je izražena u nematerijalnom obliku a u pasivi ona ima novčani iznos, ali nikada i ni pod kojim uslovima ne postoji novčani i nenovčani kapital [13].

Novčana vrednost uloga u društvo (osnovni kapital, registrovani kapital) i kasnije povećanje istog delatnošću društva i drugim osnovima čini pasivu društva (desna strana bilansa društva). U pravnom pogledu, osnovni kapital društva je pasiva društva, ali fiktivna pasiva (netražljiva pasiva), za razliku od realne pasive (tražljiva pasiva) koju čine obaveze prema trećim licima. Vrednost uloga u novcu i naturi čini početni osnovni kapital društva (izvori sredstava društva, pasiva društva), dok sami ulozi čine imovinu društva (aktiva, sredstva društva). Pravilo je da se u momentu konstituisanja društva imovina društva i njegov osnovni kapital poklapaju [13].

9 U Hrvatskoj je izmenama Zakona o privrednim društvima iz 2012. godine uvedena nova pravna forma privrednog društva ,jednostavno d.o.o. ili j.d.o.o." za koje je predviđen minimalni osnovni kapital od 10 kuna, dok je za d.o.o. minimalni osnovni kapital 20.000 kuna. Ovime se iz samog poslovnog imena, čiji je obavezni element pravna forma, vidi koliki je osnovni kapital radi sugerisanja posebnog opreza u poslovanju sa ovim društvom. O jedostavnom doo vidi više u: Brnabić, R., Ivančev, M., Jednostavno društvo s ograničenom odgovornošću, Zbornik radova Pravnog fakulteta $u$ Splitu, broj 2/2014, str. 449-469.

10 „Prodajom nepokretnosti privrednog društva ne dolazi do smanjenja osnovnog kapitala, već taj kapital samo dobija drugi oblik, tako što je umesto kapitala u stvarima pretvoren u novčani kapital“, iz presude Vrhovnog kasacionog suda, Rev. 1954/2010 od 28.10.2010. godine, ParagrafLex.

11 "Članu društva koji istupi iz društva, odnosno kome prestaje svojstvo člana društva, pripada pravo na naknadu tržišne vrednosti udela u vreme prestanka svojstva člana društva, koja nije istovetna knjigovodstvenoj vrednosti udela, već zavisi od ponude i tražnje na tržištu, pa ona može biti manja ili veća od knjigovodstvene vrednosti“. Iz rešenja Višeg trgovinskog suda, Pž. 3121/08 od 20.05.2009. godine, www.sudskapraksa.com
Lica koja su osnivačkim aktom ili na drugi način preuzela obavezu da uplate odnosno unesu u društvo određeni ulog odgovaraju društvu za izvršenje te obaveze i u obavezi su da nadoknade štetu koja je prouzrokovana propuštanjem ili kašnjenjem izvršenja te obaveze.

Novčani i nenovčani ulog prilikom osnivanja društva ili povećanja osnovnog kapitala mora se uplatiti, odnosno uneti u roku, određenom u osnivačkom aktu, odnosno odluci o povećanju kapitala, $s$ tim da se taj rok računa od dana donošenja osnivačkog akta, odnosno odluke o povećanju kapitala i ne može biti duži od:

1) u slučaju povećanja kapitala akcionarskog društva koje je javno društvo po osnovu uspešno izvršene javne ponude akcija, ili čije su akcije uključene u trgovanje na regulisanom tržištu, odnosno na multilateralnoj trgovačkoj platformi, u smislu zakona kojim se uređuje tržište kapitala, novčanim ulogom putem javne ponude - odmah po okončanju roka za upis akcija, u skladu sa zakonom koji uređuje tržište kapitala, a u ostalim slučajevima dve godine;

2) pet godina za ostala društva osim u slučaju kada se akcije izdaju u postupku javne ponude u smislu zakona kojim se uređuje tržište kapitala kojom akcionarsko društvo postaje javno akcionarsko društvo, kada se ulog mora uplatiti odmah po okončanju roka za upis akcija (član 46. ZPD).

\section{ZAKLJUČAK}

Pravno normiranje odnosno donošenje zakona po hitnom postupku, kao pravilo a ne izuzetak, simulovane javne rasprave, nekritičko prihvatanje pokreta "pravne transplantacije“, nestabilnost propisa i brza amortizacija dovode do kreiranja pravnog nereda i različitog uređenja istih pravnih instituta u različitim propisima. Ovo dovodi do problema u primeni propisa u poslovnoj praksi. Iz tih razloga potrebno je maksimalno poštovanje procedure donošenja pravnih akata uz uvažavanje struke, pravne tradicije, sistema pravnih propisa i specifičnosti pravnog poretka.

\section{LITERATURA}

[1] Babić, I., Imovina privrednog društva, Pravo i privreda broj 5-8/2004

[2] Babić, I., Osnovi imovinskog prava, Službeni glasnik RS, Beograd, 2008

[3] Babić, I., Građansko pravo, knjiga II Stvarno pravo, JP Službeni glasnik Beograd i FEPPS Nov Sad, 2012

[4] Babić, I., Građansko pravo, knjiga I, Uvod u građansko pravo, JP Službeni glasnik i FEPPS, Beograd-Novi Sad, 2011

[5] Brnabić, R., Ivančev, M., Jednostavno društvo s ograničenom odgovornošću, Zbornik radova Pravnog fakulteta $u$ Splitu, broj 2/2014

[6] Jankovec, I., Privredno pravo, službeni list SRJ, Beograd, 1999

[7] Nikčević, I., Marković, V., Poslovno pravo, Univerzitet Singidunum Beograd, 2014

[8] Paund. R., Jurisprudencija, tom II, Beogad, Službeni list SRJ - CID, Podgorica, 2000

[9] Petrović, Z., Vićentijević, K., Stanišić, N., Računovodstvo sa zbirkom zadataka, Univerzitet Singidunum Beograd, 2013

[10] Stefanović, M., Nematerijalna imovina privrednog društva, Zbornik radova Pravnog fakulteta u Nišu, broj 59/2012

[11] Stefanović, Z., Stanivuk, B., Komentar Zakona o privrednim društvima, Paragraf Co, Beograd, 2012 
[12] Stefanović, Z. Stanivuk, B., Imovina i kapital društva prema Zakonu o privrednim društvima, Pravni instruktor broj $24 / 2012$

[13] Vasiljević, M., Vodič za primenu Zakona o privrednim društvima, Intermex, Beograd, 2011

[14] Zakon o privrednim društvima Sl. glasnik RS, broj 36/2011. 99/2011, 83/2014

[15] Zakon o privrednim društvima Sl. glasnik RS, broj 125/2004

[16] Zakon o privrednim društvima Republike Srpske Sl. glasnik $R S$, broj 127/08, 58/09, 100/11, 67/13
[17] Zakon o preduzećima Sl. list SRJ, broj 29/96, 29/97, 59/98, $74 / 99,9 / 2001,36 / 2002$

[18] Zakon o osnovama svojinskopravnih odnosa, Službeni list SFRJ, br. 6/80, 36/90, Službeni list SRJ, br. 29/96, Službeni glasnik RS, br. 115/2005

[19] Zakon o stečaju ("Službeni glasnik RS”, br. 104/2009, 99/2011, 71/2012 (Odluka Ustavnog suda), 83/2014

\section{ASSETS, NET ASSETS (EQUITY) AND THE STATED CAPITAL OF THE COMPANY}

\section{Velisav Marković}

Faculty of Busines in Valjevo, Singidunum University, Zeleznicka 5, Valjevo, Serbia, vmarkovic@singidunum.ac.rs

\section{Abstract:}

The Law on Companies stipulates that the company's assets consists of assets and rights in companies proprietorship, as well as other rights, that net assets (equity) of the company is the difference between the value of assets and liabilities of the company and that the initial (registered) capital of the company is monetary value of enrolled shares belonging to company members, which is registered in accordance with the law on registration. These definitions are quite vague and laymen which can create problems in business practice. In this article, the author analyzes the basic legal concepts of assets, net assets and the initial capital of the company in order to illuminate these concepts and make them understandable.

\section{Key words:}

assets,

the assets of the company,

the net assets (equity), initial capital. 